Nutr. Metabol. 1974;17:I-VI

\title{
Contents, Vol. 17, 1974
}

Nutrition and Metabolism

Journal of Nutrition, Metabolic Diseases and Dietetics

Main Editor N. Zöllner, München

Associate Editor E.M. Widdowson, Cambridge G. Wolfram, München

Editorial Board W. Auerswald, Wien R. Gitzelman, Zurich /. Macdonald, London

K.J. Carpenter, G. Hartmann, Chur H.K. Mangold, Münster

Cambridge C. Den Hartog, Rijswijk K.R. Norum, Oslo

H.-D. Cremer, Giessen K. Hellström, Stockholm G. Schlierf, Heidelberg

J.W.T. Dickerson, S. Heyden, Durham, N.C. J.C. Somogyi, Zurich

Guildford F.A. Hommes, Groningen /. Trêmolières, Paris

F. Falkner, B. Jacotot, Créteil A.J. Vergoesen,

Yellow Springs, Ohio H. Kapp, Basel Vlaardingen-Duiven

F. Fidanza, Perugia E. Kodicek, Cambridge A. Wretlind, Stockholm

S. Karger $\cdot$ Basel $\cdot$ München $\cdot$ Paris $\cdot$ London $\cdot$ New York $\cdot$ Sydney

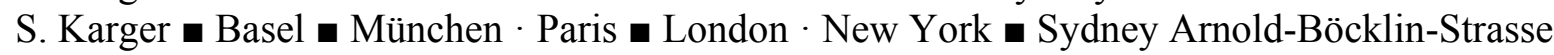
25, CH-4011 Basel (Switzerland)

All rights, including that of translation into other languages, reserved. Photomechanic reproduction (photocopy, microcopy) of this volume or parts thereof without special permission of the publishers is prohibited.

(C) Copyright 1974/75 by S. Karger AG, Verlag für Medizin und Naturwissenschaften, Basel

Printed in Switzerland by Thür AG Offsetdruck, Pratteln

Index

No. 1

Seetharam Bhat, K. and Gopalan, C. (Hyderabad): Human Cataract and Galactose

Metabolism 1

Misra, R.; Misra, U.K., and Venkitasubramanian, T.A. (Delhi): Incorporation of

Plamitate-1-I4C into Liver Lipids of Rats Fed Millet (Sorghum vulgarie) at

Different Protein Levels

9

Ågren, G.; Stenram, U.; Nordgren, H.; Eklund, A., and Glas, J.E. (Uppsala): Some

Biological Effects Observed in Rats Fed on Single Cell Proteins of Yeast and

Bacterial Origin

20

MacRae, A.R.; Slinger, S.J., and Neudoerffer, T.S. (Guelph, Ont.): Studies on Carbo hydrate Digestibility and Weight Gain Response in Rats Fed Dietary Sucrose,

Glucose or Fructose 37

MacRae, A.R.; Nickel, I.; Slinger, S.J., and Neudoerffer, T.S. (Guelph, Ont.): Carcass

Composition and Weight Gain Response of Rats Fed Various Carbohydrates at

Two Dietary Levels of Carbohydrate and Protein 47

Krishnaswamy, K. (Hyderabad): Methionine Metabolism in Pyridoxine Deficiency . 55 
Varia 64

No. 2

Heijenoort, Y. van; Sacquet, E. et Riottot, M. (Gif-sur-Yvette): Degradation bactérienne de Tacide $/ 3$-muricholique chez le rat 65

Vrána, A.; Fábry, P.; Slabochová, Z., and Kazdová, L. (Prague): Effect of Dietary

Fructose on Free Fatty Acid Release from Adipose Tissue and Serum Free

Fatty Acid Concentration in the Rat 74

Hambraeus, L.; Hardell, L.I.; Forsum, E., and Lorentsson, R. (Uppsala): Use of a

Formula Based on a Whey Protein Concentrate in the Feeding of an Infant with

Hyperphenylalaninemia $\quad 84$

Index IV

Gallenkamp, H.; Brachtel, D.; Sundermann, D.; Griin, M.; Rietbrock, I., and Richter,

E. (Würzburg): Ethylmorphine- $\Lambda$ f-Demethylase Activity and Thiopentone Half-

Life in Rats Fed a Choline-Deficient Diet 91

Andersson, H. (Göteborg): Fat-Reduced Diet in the Symptomatic Treatment of

Patients with Ileopathy. A Follow-Up Study 102

Chen, M.L.; Huang, C.S., and Chen, J.S. (Taipei): Dietary and Nutritional Study on

Aborigines in Taiwan 112

Gamulin, S. and Norman, M.R. (London): Effects of Fasting on the Activity of

Cytosol Factors Engaged in Protein Biosynthesis in Mouse Hepatocytes 121

Book Reviews - Buchbesprechungen · Livres nouveaux 127

Varia 128

No. 3

Tyagi, K.P.; Mukhopadhyay, A.K.; Argawal, H.H.; Naik, S.R.; Gauri Bazaz Malik;

Gupta, D.N., and Chuttani, HK. (New Dehli): Gastric Mucosal Morphology in

Tropics and Influence of Spices, Tea and Smoking 129

Vogtmann, H.; Clandinin, D.R., and Hardin, R.T. (Edmonton, Alta.): Utilization of

Rapeseed Oils of High and Low Erucic Acid Content. II. Influence on Tissues . 136 Lai, H. and

Agarwal, K.N. (Varanasi): Influence of Hormones on Free $\alpha$-Amino

Nitrogen Alterations in Plasma, Erythrocyte and Leucocyte in Rats

Lee, H.A.; Down, P.F.; Fowell, E., and Hyne, B.E.H. (Southampton): Amino Acid

Tablet-Substituted Diets in the Management of Chronic Renal Failure 154

Nettleton, J.A. and Hegsted, DM. (Boston, Mass.): The Effects of Protein and

Calorie Restriction on Tissue Nitrogen Content and Protein Catabolism 166

Jefferys, D.B. and White, I.R. (London): The Resistance of the Mature Female Rat to

Protein Deficiency 181

Book Reviews - Buchbesprechungen · Livres nouveaux 189

No. 4

Editorial

Den Hartog, C. Rijswijk): Diet and Coronary Heart Disease

193

Original Paper

Marthens, E. van and Grauel, L. (Los Angeles, Calif.): Ovarian, Adrenal and Litter

Restriction Effects on Fetal and Placental Development 198

Schraer, K.K. and Calloway, D.H. (Berkeley, Calif.): Zinc Balance in Pregnant Teen agers 205

Beare-Rogers, J.L.; Nera, E.A., and Heggtveit, H.A. (Ottawa): Myocardial Alteration 
in Rats Fed Rapeseed Oils Containing High or Low Levels of Erucic Acid .... 213

Index

$\mathrm{V}$

Mahoney, A.W.; VanOrden, C.C, and Hendricks, D.G. (Logan, Utah): Efficiency of

Converting Food Iron into Hemoglobin by the Anemic Rat 223

Kumar, S. and Jay a Rao, K.S. (Hyderabad): Blood and Urinary Zinc Levels in

Diabetes Mellitus 231

Heinrich, H.C.; Gabbe, E.E.; Bríiggemann, J., and Oppitz, K.H. (Hamburg): Effects of

Fructose on Ferric and Ferrous Iron Absorption in Man. Within-Subject Study

with the S9 Fe-Absorption Whole-Body-Retention Test in Subjects with Normal

and Depleted Iron Stores 236

Herrlinger, H.; Zöllner, N., and Wetzstein, R. (München): Electron Microscopic

Evidence of Severe Muscular Capillary Damage in an Alcoholic Patient with

Cardiac Myopathy 249

Book Reviews · Buchbesprechungen $\mathbf{m}$ Livres nouveaux 259

No. 5

Editorial Heyden, S. (Durham, N.C.): Koffein auf der Anklagebank - Quousque tandem? . . 261

Original Paper Zöllner, N. and Herrlinger, H. (München): Thickness of Basal Laminas in Muscle

Capillaries of Patients with Hyperlipidemias 268

Grimble, R.F. and Dickerson, J.W.T. (Guildford): The Influence of Iso-Energetic

Amounts of Sucrose and Starch on Serum Albumin Concentrations and Liver

Composition of Weanling Rats Given a Low-Protein Diet 272

Vràna, A.; Fábry, P., and Kazdová, L. (Prague): Lipoprotein Lipase Activity in Heart,

Diaphragm and Adipose Tissue in Rats Fed Various Carbohydrates 282

Válek, J.; Slabochová, Z.; Grafnetter, D., and Kohout, M. (Prague): The Importance

of Stimulated Immunoreactive-Insulin Levels to Early Results of Dietary

Management in Hyperlipoproteinemia 289

Stock, M.J. and Stuart, J.A. (London): Thermic Effects of Ethanol in the Rat and

Man 297

Birchwood, B. (Toronto, Ont.): Primary Systemic Amyloidosis with Bone Lesions

Presenting as Hyperlipoproteinemia. Case Report 306

Bartov, I.; Henderson, G.R., and Reiser, R. (College Station, Tex.): Sex Differences

in Steroid Retention and Excretion in Rats Fed Cholesterol 312

Varia 320

No. 6

Editorial

Heyden, S. (Durham, N.C.): Polyunsaturated Fatty Acids and Colon Cancer

Index VI

Original Paper Abrahamsson, H.; Gustafson, A., and Ohlson, R. (Göteborg): Polyunsaturated

Fatty

Acids in Hyperlipoproteinemia. I. Influences of a Sucrose-Rich Diet on Fatty

Acid Composition of Serum Lipoprotein Lipids 329

Svanberg, U.; Gustafson, A., and Ohlson, R. (Göteborg): Polyunsaturated Fatty

Acids in Hyperlipoproteinemia. II. Administration of Essential Phospholipids in

Hypertriglyceridemia 338

Nasseri, M.; Mohagheghpour, N., and Khakpour, M. (Teheran): Effects of Dietary 
Supplementation on the Humoral Immune Response of Malnourished Mice . . 347 Raptis, S.; Berger, L. von; Dollinger, H.C.; Gostomzyk, J.G., and Pfeiffer, E.F. (Ulm):

Influence of Ethanol, Caffeine and Intragastric Cooling on Gastrin and Insulin Secretion in Man 352

Evans, E.; Stock, A.L., and Yudkin, J. (London): The Absence of Undesirable

Changes during Consumption of the Low Carbohydrate Diet 360

Lindenbaum, E.S. and Mueller, J.J. (Haifa): Effects of Pyridoxine on Mice after Immobilization Stress 368

International Union of Nutritional Sciences 375

Book Reviews · Buchbesprechungen · Livres nouveaux

Indexes

Subject Index 379

Author Index 382 